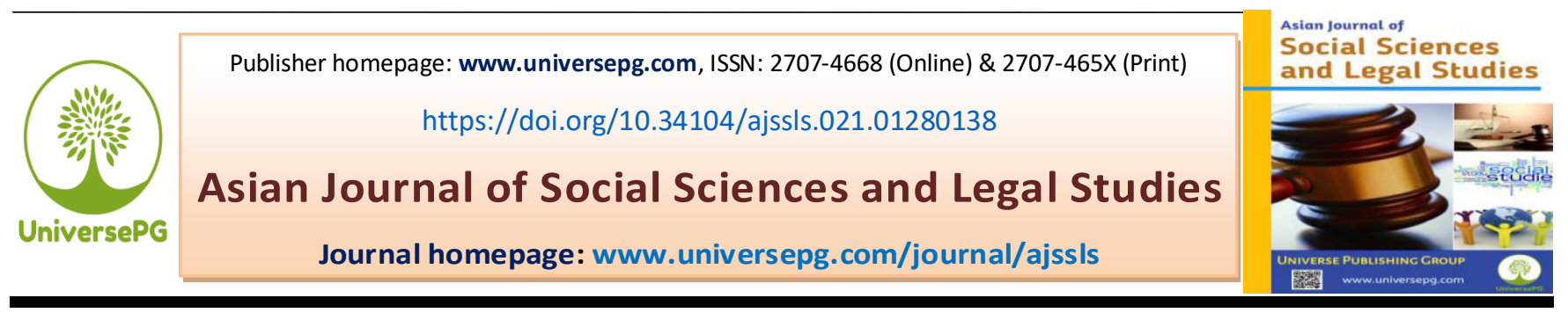

\title{
The Present Scenario of Women Laborer in the Informal Sector: A Study on Dhaka city
}

\author{
Mst. Tahmina Sultana ${ }^{1 *}$, Md. Mokter Ali ${ }^{1}$, Rehena Parvin ${ }^{1}$ and Mahmudul Hasan ${ }^{1}$ \\ ${ }^{1}$ Dept. of Sociology and Social Work, Gono Bishwabidyalay (University), Mirzanagar, Savar, Dhaka-1344, Bangladesh. \\ *Correspondence: tahmina.gono@gmail.com (Mst. Tahmina Sultana, Assistant Professor, Dept. of Sociology and Social \\ Work, Gono Bishwabidyalay, Mirzanagar, Savar, Dhaka-1344, Bangladesh).
}

\begin{abstract}
Informal sectors play a significant role in the economic growth of Bangladesh. Here women workers are the main impetus factor for economic growth. So, the key objective of our research was to find out the present situation of women laborers in the informal sector and they are facing such problems in their working place. We have selected 60 women from the informal industrial area of Dhaka city. This area of different field and the majority of them were from garments sector, those are $43 \%$. We have collected their demographic and socioeconomic information to understand their livelihood process. We found utmost of them are 25-30 years old and $50 \%$ of workers are married. $82 \%$ of employees live in a nuclear family because most working women earn 6000-7000 taka (which is $22 \%$ ) which is not sufficient to maintain a joint family. This research also finds that $70 \%$ of the workers are migrated from rural to urban areas and they have left their families behind in the villages. There are a lot of causes for them to migrate. This study also finds very important and shocking data that almost every woman (99.33\%) is facing several types of problems in their workplaces. Our intention of this research was to trace out the real scenario of the present situation of women workers in the informal sector and we have attempted our best to do. The researcher, to develop the present condition and banishing the obstructions for the women laborer in their working place, this study will be helpful to the policymakers and a proper policy can be introduced by the appropriate authority of Bangladesh for the welfare of women the informal sector workers. That will help the nation to gain more economic growth.
\end{abstract}

Keywords: Women laborer, Informal sector, Garments, Problems in workplaces, Empowerment, and Dhaka city.

\section{INTRODUCTION:}

In many segments of the workplace, the working environment is more challenging for women. According to Marxist Theories before slavery, women were the executives of society. When the conception of "Private property" arises, the society became patriarchal and the working environment for women became worse. They become the slave of society. In Asia, the present situation and problems for women UniversePG I www.universepg.com laborer are in a rogue state instead of the other than the world. A survey indicates that there are 487 million workers in Asia. Among them, 300 million earns less than $1 \$$ per day and lives below the poverty line (ILO, 2008). This survey also finds that $50 \%$ populations of the world are vulnerably employed. Labour markets are distinguished in formal and informal sectors. Workers who do not get jobs in formal sectors become the worker of the informal sector on account of their 
necessity. In 1971 Keith Hart used the concept "Informal Sector" at the beginning (Chowdhury, 2005) and International Labor Organization (ILO) popularized it.

The rapid expansion of Bangladesh economy mostly depends on the informal sectors. In 2002 the informal sector created $79 \%$ of the jobs of the whole labor market and contributed $43 \%$ of the total GDP of the nation. The informal sector is most effectively working in rural areas than the urban areas. Women employees are significant part of the informal economy. 93\% of women are engaged in the informal sector where $87 \%$ of men (The economic census, 2013). The quarterly LFS founds, in present times women's participation is increasing gradually in manpower (Yasmin and Husna, 2020). Where it was $4 \%$ in 1974 it has been an expansion to $35.6 \%$ in 2016. It is much more rapid than the increase of the involvement of male laborer.

Which is $80.4 \%$ in 1974 to $81.9 \%$ in 2016? Participation of urban women is increasing a little bit slower $(30.8 \%)$ than the increasing rate of countryside women $(37.6 \%)$. Besides the contribution of increasing rate in export-oriented readymade garments sectors women's participation is increasing in many emerging and non-traditional sectors like transportation, hotels and restaurants, real estate services, banking, and telecommunication. But at the country level, only $4.6 \%$ of all employed female are participated in the formal sector compared to $17.7 \%$ of their male complement. LFS shows us an ugly truth that the involvement of women in the labour force is lower than the involvement of men. It is happening because of some intervening obstacles for women. So, this study focused to trace out the obstacles for women to participate actively in the informal working force.

\section{Literature Review}

The achievement of women labor to the financial progress of Bangladesh is outstanding. Especially with the innovation of the garment industry in Bangladesh, the matter of women's labor is deliberated as an important force of labor. Till now women's labor force is the key labor sources of any garments industry in Bangladesh. Not only Bangladesh but also its globally main labor sources. Here we considered about the informal sector is especially for women labor. Bangladeshi women are making a remarkable contribution to the informal sector; in these circumstances, Bangladesh's GDP growth has increased at a high rate than in the formal decade through women labor. Thus, the intimate relationship of women labor with GDP growth. The Informal sectors mean that governmental or non-governmental works/jobs. The men who are working for a particular time or periods in her/him own working sector that also called self-employed, or those men/ women who earn by a particular work that are not payrolls its call the informal sector. According to (Aditi Kapoor, 2007), self-employed, casual, migrant, own-account, contractual, home-based work is call informal sectors ${ }^{1}$. Another definition, in (1972) ILO define the conception of informal sectors it's also that Kenya Mission Report, way of doing things characterized by -easy of entry, -reliance on indigenous resources, -family ownership; -minor scale operations; -labor exquisite and adaptable technology; -efficiency acquired beside of informal sector; -unregulated and competitive markets. During that time, several scholars defined the informal sector by the ILO itself ${ }^{2}$. Farrel, (2000) define, the informal sector as which entails economic actions which are not logged in the GDP and the domestic profits accounts ${ }^{3}$. To (Ojo, 1981) define the informal sector comprises minor scale units involved in properties construction and distribution and facilities with the prime objectives of producing employs and income, nonetheless the constraints on capital, both corporal and human, and the technical knowledge ${ }^{4}$. Ademu, (2006) identify the informal sector, "is that informal sector includes those employ producing activities accepted for survival in the nonattendance of formal employ ${ }^{5}$. These activities are generally conducted short of proper gratitude from the authorities \& outflow the judgment of the administration equipment responsible for applying rule and regulation ${ }^{6}$. In the

\footnotetext{
${ }^{1}$ The SEWA way: Shaping another future for informal labour, Elsevier, Futures 39 (2007), 554-568.

${ }^{2}$ Role of Women in Informal Sector in India.

${ }^{3}$ Globalization and employment Generation" Evaluating the impact of trade on Aggregate employment in Nigeria's In Industrial Sector.

${ }^{4}$ Nigeria's Manpower Planning Experience.

${ }^{5}$ The informal sector and employment generation in Nigeria: The role of credit.

${ }^{6}$ A Socio-economic Study of Informal Sector Workers of Dhaka City.
} 
consideration of the explanation of the figure about informal sector that research scholar mentioned upon the discussion, we understand that; Refers to women's employment in informal sector like household work, self-employment work, day labor work, personal ownership works, and self-minor opportunities work. So, those research papers could not focus on facing the existent problem of informal sectors. This research investigates the catchment area that the previous researcher had not properly tried to investigate in informal sectors in Dhaka, Bangladesh.

\section{Rational of the study}

Bangladesh is a developing country in the world. It is a high densely populated country with a population of $166,060,868$. About $90 \%$ populations in Bangladesh live below the poverty line. So, both men and women have to involve themselves in economic activities to maintain their livelihood. The involvement of the women workers in Bangladesh expansion at significantly more desperately than of man from 20162017. From the information of the Bureau of Statistics in Bangladesh, the women laborers gradually increased by $4.6 \%$ when the male labour increased by $1 \%$. The significant growth of women labour was a symbol of women empowerment. But in a maximum of the sectors, female laborer does not get any safety. There is not any specific national policy at present on the safety net issue and very little discussion took place in society in this consideration. We realize that many laws are taken for female laborer safety net such asIndustrial Relation ordinance 1969, Workers' compensation at 1929, Payment and wages Act-1936, Maternity Act-1936, Factory Act -1965, Employment of labour (So) 1965 etc. But most of the labour laws are backdated with weak enforcement by concerned authorities. As a result, women workers are suffering from a wicked working environment and poor wages, quality and security are disregarded. Bangladesh is a male-dominated community in which women are treated unequally. It starts from the family and goes up in different sectors like the informal sector in outside world. Consequently, they face challenges to join outside the workforce like the informal sector. Their household members sometimes forbid them to go the outside at home. At the level of family, where women's voice is not heard, and thus, it shows the dis- empowerment of women in their family. In the outside world, exploitation of the informal women workers stresses from the very deigning of their recruitment process. Most of the women workers are not given formal job contract papers during their recruitment process. Sometimes they are victims of sexual and verbal abuse by their working place. Wage discrimination is a general scenario in the informal sector between male and female laborer. So, to realize the real situation of these issues we should accomplish an investigation of study. Moreover, no influential research study had been taken on the difficulties and perspectives of women worker in the informal sector. This research will be capable to trace out the difficulties and perspectives of women working in the informal sector in Dhaka, which creates the opportunity the further study in this consideration.

\section{Objectives}

The key objectives of this research to trace out the present situation and difficulties of female workers from informal sector in Dhaka City. There are some other specific objectives, and these are as follows:

- To know the demographic and socio-economic conditions of women workers of informal sector.

- To analyze their working pattern and working facilities.

- To know about their participation in decision making.

- To appoint the problems, they are facing in their working sectors.

- To take opinion towards their betterment.

\section{Ethical Consideration}

The morality of the study was rigorously followed throughout this research. Each respondent was examined as exceptional and was abided with due regarded as an individual. Firstly, the explorer built up against intimacy with the respondents and them described the objective of the research. Discernment mood was followed in this consider which signify that no respondent would be justified whether she was correct or not in the event of her tusks or behavior.

\section{METHODOLOGY:}

The main method of the research was the social survey. We have followed qualitative and quantitative approaches too. 


\section{Sampling}

The research has been accomplished among the informal female workers those work in different informal sectors in the Savar area of Dhaka city. The study involved a non-probability sampling technique to draw the necessary sample from the target population. For these research 60 women, informal sector laborer was selected as a sample based on purposive sampling technique from the different informal sectors where they work.

\section{RESULTS AND FINDINGS:}

\section{Socio-economic and Demographical Features of the Participant}

Table 1: Socio-economic and Demographical features.

\begin{tabular}{|c|c|c|}
\hline Indicators & Determinant & $\mathrm{N}=60(\%)$ \\
\hline \multirow[t]{6}{*}{ Age } & $15-20$ & $18.33 \%$ \\
\hline & $20-25$ & $13.33 \%$ \\
\hline & $25-30$ & $28.33 \%$ \\
\hline & $30-35$ & $21.67 \%$ \\
\hline & $35-40$ & $1.67 \%$ \\
\hline & 40-up & $16.67 \%$ \\
\hline \multirow[t]{8}{*}{ Occupation } & Day labor & $23 \%$ \\
\hline & Block-batik & $7 \%$ \\
\hline & Garments Worker & $43 \%$ \\
\hline & Flower seller & $7 \%$ \\
\hline & Plastic worker & $10 \%$ \\
\hline & Packet maker & $2 \%$ \\
\hline & Hawker & $3 \%$ \\
\hline & Tailoring & $5 \%$ \\
\hline \multirow[t]{5}{*}{ Marriage Pattern } & Married & $50 \%$ \\
\hline & Unmarried & $16.67 \%$ \\
\hline & Divorce & $15 \%$ \\
\hline & Widow & $6.67 \%$ \\
\hline & Separated & $11.67 \%$ \\
\hline \multirow[t]{2}{*}{ Family Pattern } & Single & $81.67 \%$ \\
\hline & Joint & $18.33 \%$ \\
\hline \multirow[t]{3}{*}{ Family Members } & $1-2$ & $35 \%$ \\
\hline & $3-4$ & $48.33 \%$ \\
\hline & $5-6$ & $16.67 \%$ \\
\hline \multirow[t]{4}{*}{ Religion } & Islam & $85 \%$ \\
\hline & Hinduism & $8.33 \%$ \\
\hline & Buddhism & $5 \%$ \\
\hline & Christianity & $1.67 \%$ \\
\hline \multirow[t]{7}{*}{ Educational Status } & Illiterate & $5 \%$ \\
\hline & Sign Only & $8.33 \%$ \\
\hline & Under Class Five & $16.67 \%$ \\
\hline & Class five to seven & $36.67 \%$ \\
\hline & Class seven to nine & $10 \%$ \\
\hline & SSC & $21.67 \%$ \\
\hline & HSC & $1.67 \%$ \\
\hline \multirow[t]{3}{*}{ Monthly wages (in BDT) } & $3000-4000$ & $5 \%$ \\
\hline & $4000-5000$ & $40 \%$ \\
\hline & $5000-6000$ & $1.66 \%$ \\
\hline
\end{tabular}

UniversePG I www.universepg.com

\section{Data collection and analysis technique}

In this research primary and secondary sources of data, both are considered. To achieve the goal of the research we used a pre-tested interview schedule and observation method to collect data. The collection of statistical tool like mean and percentages was used to analyze data. For processing and analysis purpose we also used SPSS, MS Excel, and MS Word. Table bar diagrams and pie charts had been applied for the presentation of data. data was shorter and processed for analysis. A simple 


\begin{tabular}{|l|c|c|}
\hline \multirow{4}{*}{} & $6000-7000$ & $21.66 \%$ \\
\cline { 2 - 3 } & $7000-8000$ & $6.66 \%$ \\
\cline { 2 - 3 } & $8000-9000$ & $8.33 \%$ \\
\cline { 2 - 3 } & $9000-10000$ & $3.33 \%$ \\
\hline \multirow{4}{*}{ Monthly Expenditure (in BDT) } & $10000-\mathrm{up}$ & $13.33 \%$ \\
\cline { 2 - 3 } & $4000-5000$ & $38.33 \%$ \\
\cline { 2 - 3 } & $6000-7000$ & $30 \%$ \\
\cline { 2 - 3 } & $8000-9000$ & $16.67 \%$ \\
\hline
\end{tabular}

Here all the respondent or female workers are directly engaged in the informal sector. The highest 30 respondents (50\%) among 60 respondents are married. 10 respondents $(16.67 \%)$ are unmarried. 09 respondent (15\%) are divorce, 07 respondents (11.67\%) are included to Separated. The lowest number 4 respondents $(6.667 \%)$ are a widow. In this research, we found that $81.67 \%$ of respondents are a nuclear household and are $18.33 \%$ are a joint family. Among $48.33 \%$ of bear 3-4 family members, 21 respondents (35\%) bear 1-2 family members, 10 respondents $(16.67 \%)$ bear 5-6 family members and the mean number of family members 3.13. The table represents that the highest 51 respondents $(85 \%)$ of 60 respondents are Muslim, 5 respondents $(8.333 \%)$ are Hindu. 01 respondent (1. $67 \%)$ are Christian, 3 respondents (5\%) are Buddha.

Due to several social, economic, cultural problems women of our country do not get the proper opportunity to be literate. So, many women involve themselves in informal sectors. This research shows that 5 $\%$ of the total workers are illiterate and $8.33 \%$ can sign only and $16.67 \%$ of the respondents have educated underclass five. Class five to seven $36.67 \%$ of those are completed class five to seven. $21.67 \%$ of respondent completed SSC which is mostly employed in the garments sector. The lowest percentage 1.68\% shows that HSC educational qualification. Remuneration, additionally a fringe benefit, is the determining factors of socio-economic position and life standard of female workers. It exposes that most of the respondents (24) $40 \%$ monthly wage is Tk. 4,0005,000 . The number of respondents who are earned the highest monthly wages Tk.10, 000.00 or above is (8) $13.33 \%$ and the lowest monthly wages Tk. 3,000.00$4,000.00$ are (3) $5 \%$ and the mean monthly wages of the whole respondent are Tk. 6,100.00 only. We can say that the female worker does not get enough wages because they worked in the lower level and unskilled job. At present living cost in Dhaka is very large. It is too troubled by the number of family members. In this research, it is shown that maximum families have 3-4 dependent members whose expenses are borne by only 1-2 earning members. The monthly expenditure of 23 respondents $(38.333 \%)$ are Tk. 4000-5000, 18 respondents (38\%) are 6000-7000 Taka, 10 respondents $(16.667 \%)$ are $8000-9000$ and the lowest 9 respondents (15\%) family expenditure are 10000-above. Their average monthly expenditure is $7100 \mathrm{Tk}$. The wage of the laborer constantly is not always enough to provide meats, but they manage it somehow by living marginally.

The reasons to migrate in Dhaka - Migration at Entire family, to follow the others, \& to fulfill the economic crisis. Informal women workers are migrated to Dhaka for various kinds of reasons. The above table shows that $71.67 \%$ of the participant moved to Dhaka due to unemployment and $83.33 \%$ due to poverty, $60.67 \%$ due to natural trouble, $46.67 \%$ due to landless, $41.67 \%$ due to other cases i. e. immigration of entire family to follow the others and to fulfill the economic crisis, respectively (Fig 1).

From the Fig 2, shows that highest $43.33 \%$ of female workers among 60 respondents work in garments sectors, $6.67 \%$ engaged in block-batik, $23.33 \%$ in day labour, $6.67 \%$ in flower seller, $10 \%$ in plastic worker, $5 \%$ in tailor, $3.33 \%$ in hawker, respectively. And an in significant amount of the participant $1.67 \%$ in packet maker.

Facilities in the working places - Though there have huge problems the informal women workers get some facilities which are essential for them. Maximum of the participants $(58.33 \%)$ get their salary due time, $53.33 \%$ of the participants get their bonus/incentives, $33.33 \%$ get overtime, $20 \%$ get transport facilities, $8.33 \%$ get an accidental allowance, $33.33 \%$ get a 
medical allowance and $60 \%$ get weekly leave, respectively. Nazmul Alam, (2012), found more than 10 hours are working each day of female in informal sector. But they do not evaluated by their laborer hours (Fig 3).

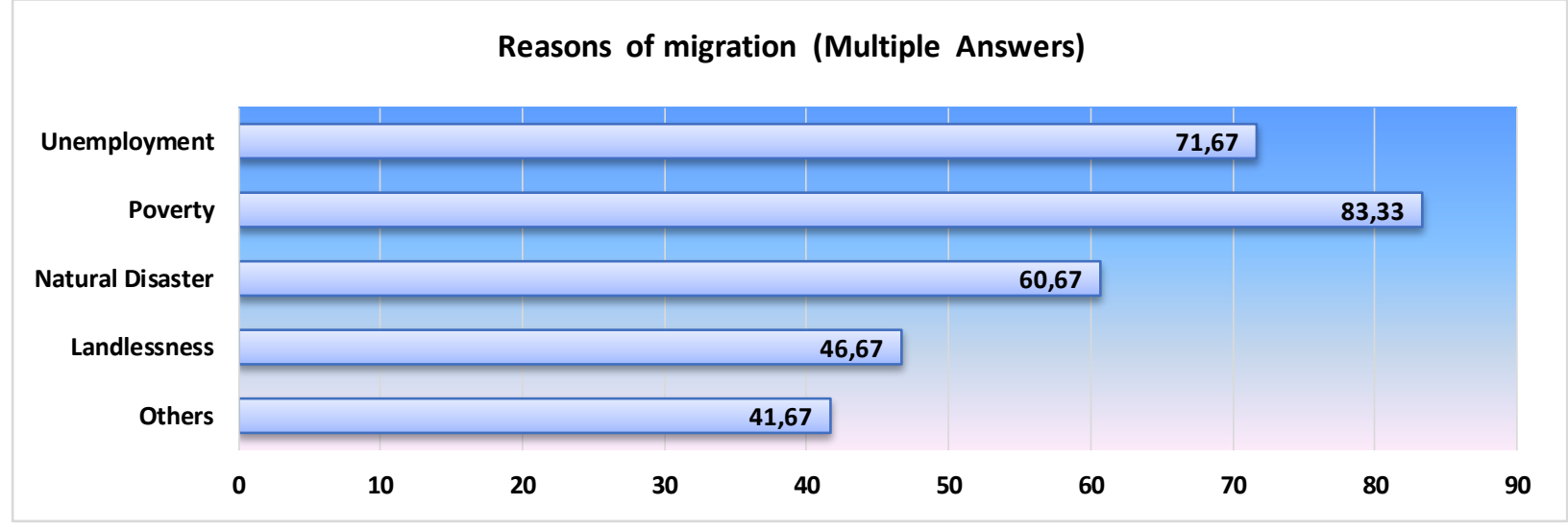

Fig 1: Reasons of migration (Multiple answers).

\section{Types of works}

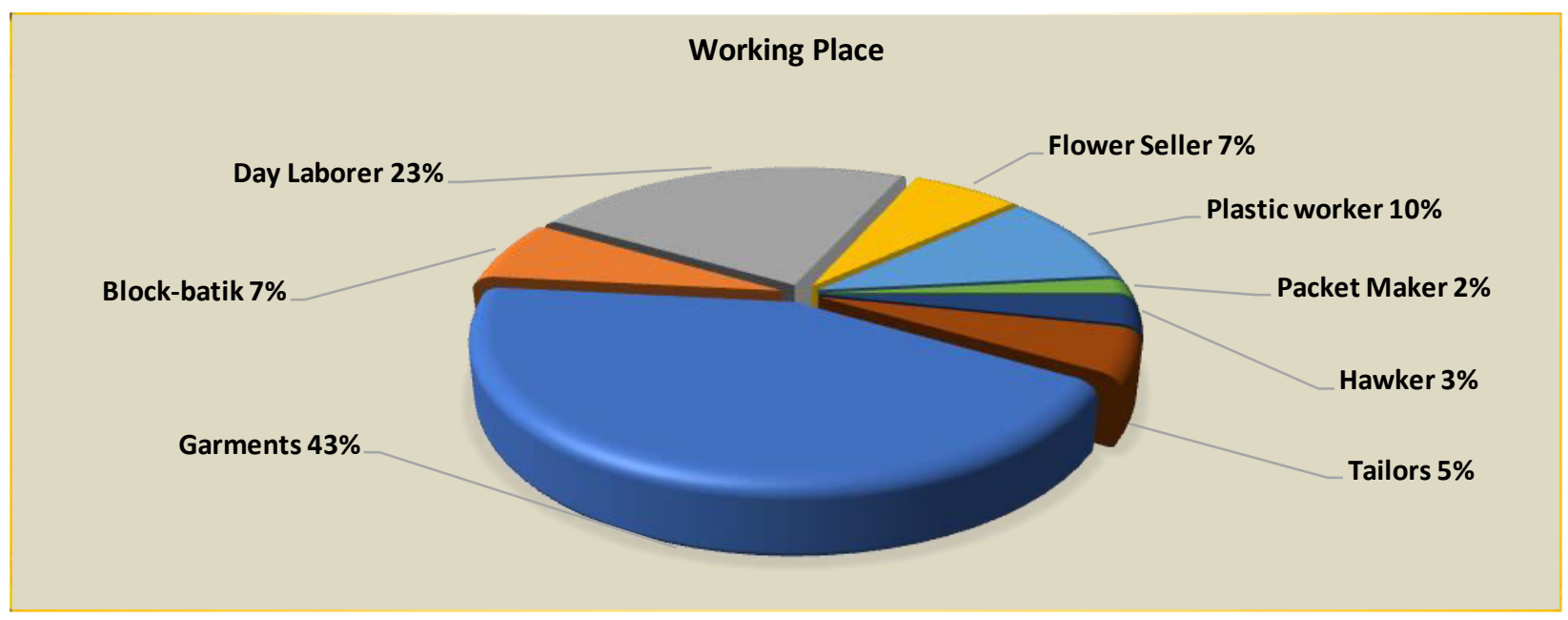

Fig 2: Working place.

\section{Facilities in the working place}

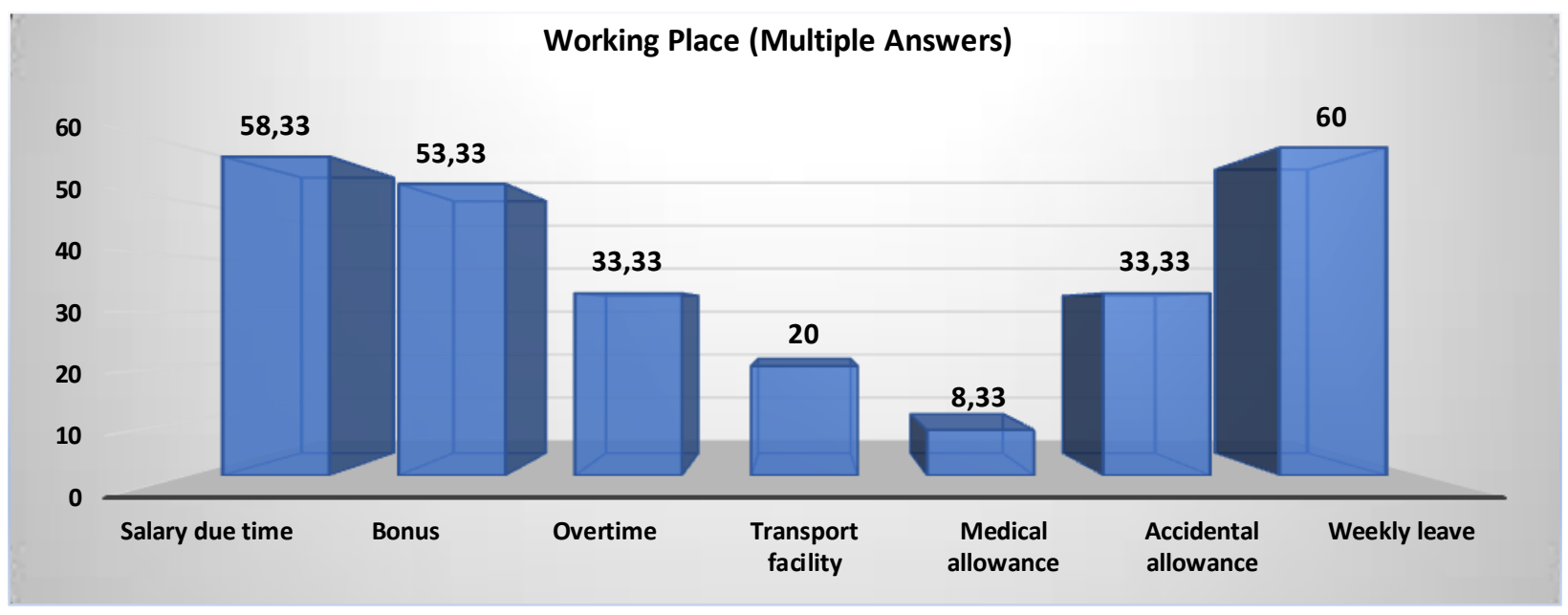

Fig 3: Facilities of working place (Multiple answers). 


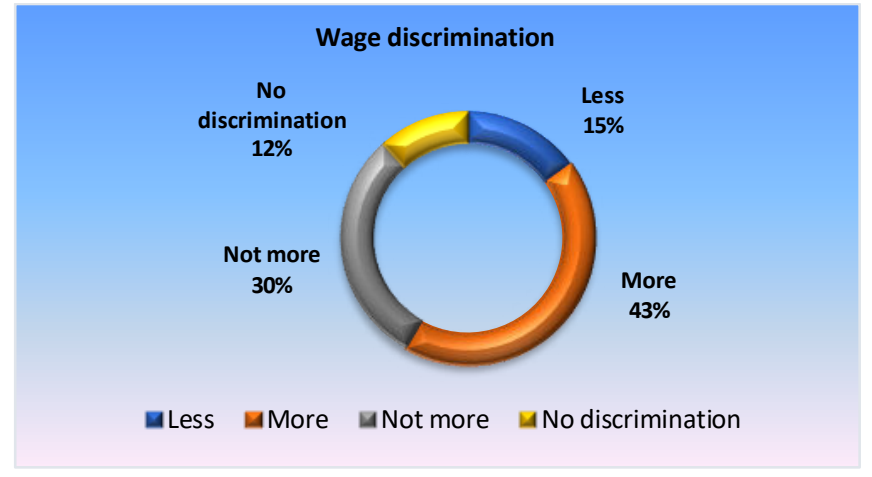

Fig 4: Wage discrimination.
Wage discrimination is a regular scenario in informal sector interim male and female labour. This study found that the maximum number of female workers $43 \%$ face more wage discrimination, $30 \%$ of the participant indicated that their wage discrimination is medium. Elsewhere, only $15 \%$ of female workers said that they face less discrimination in their working places. A very few numbers of women workers $12 \%$ reported that there is not any discrimination in their working place (Fig 4).

\section{Decision making opportunity in the family}

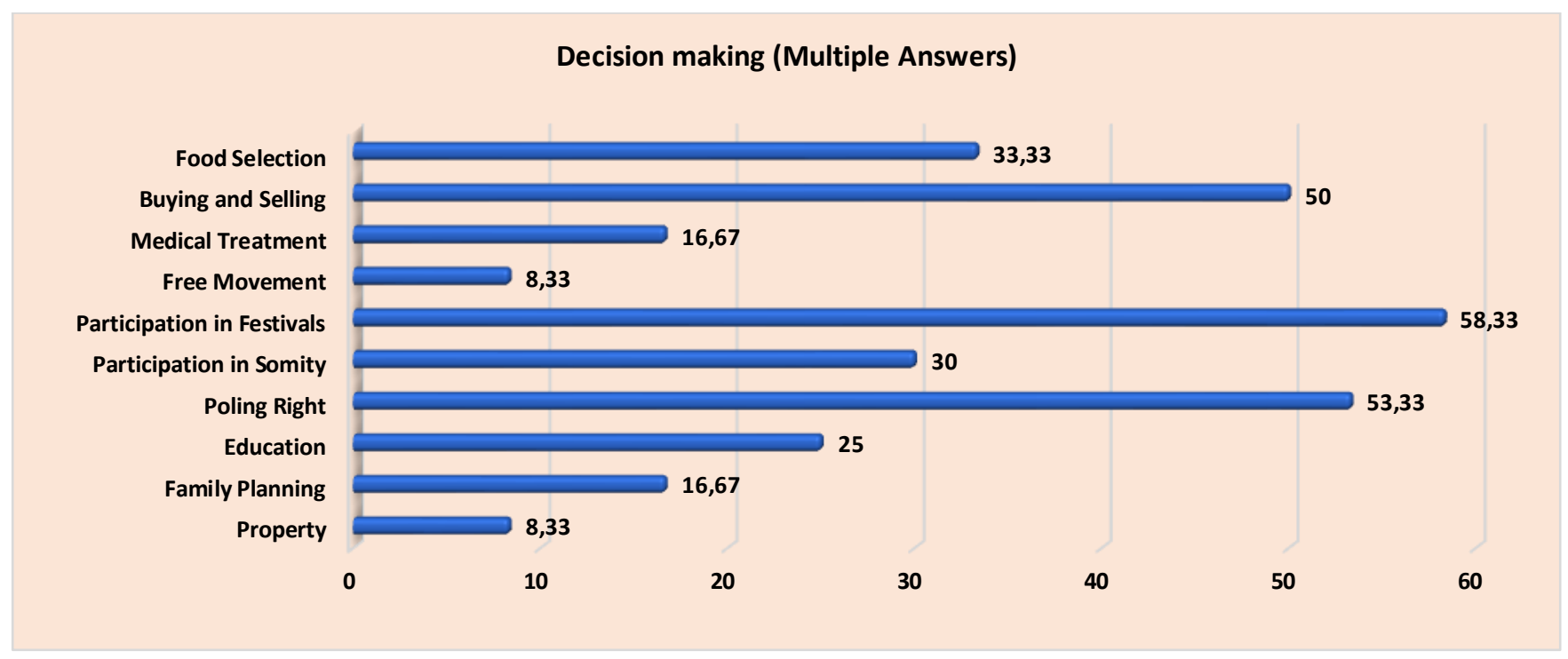

Fig 5: Decision making (Multiple answers).

\section{Women workers facing problem in the workplace}

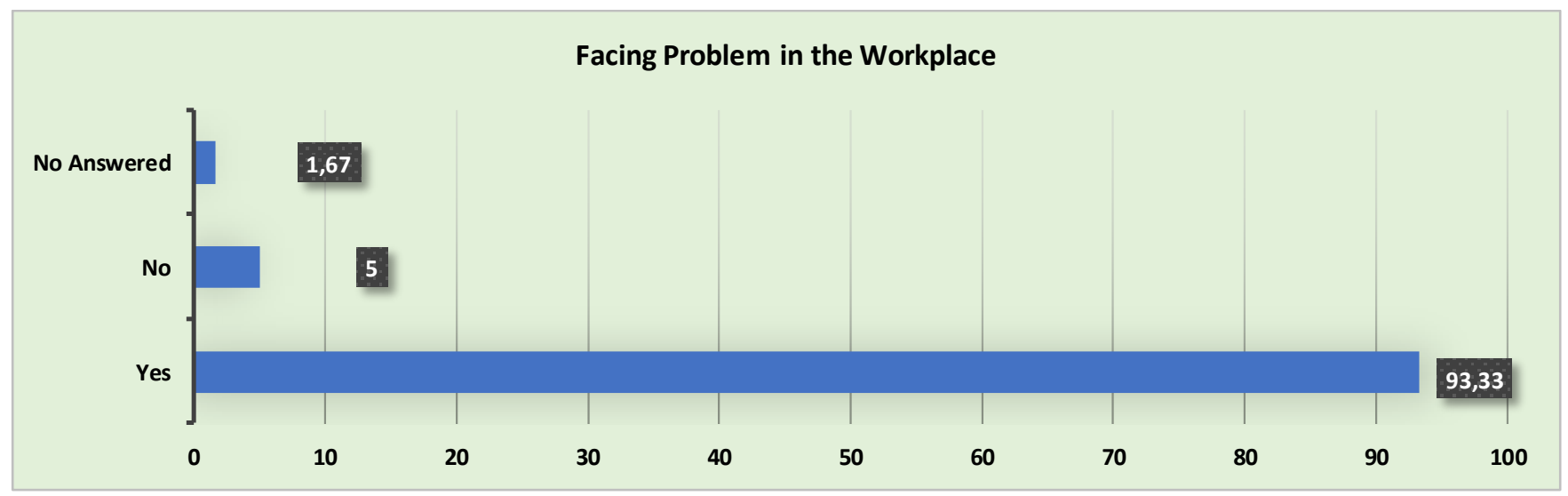

Fig 6: Facing problem in the workplace.

In Bangladesh, women are improving gradually through the involvement of female in different activities. The involvement of the informal sector is distinct of them. The research found that the female UniversePG I www.universepg.com workers who get the benefit to perform in the decision making process are not sufficient level in their family. The highest respondent $58.33 \%$ can participate in festivals. The second highest respondent 
$53.33 \%$ can ensure their polling right. $25 \%$ of the female can give their opinion to education or institutional learning about themselves as well as their children. $16.667 \%$ of women worker can give their opinion to both conceive a child and taking medical treatment. $30 \%$ of women workers engage themselves in somity. An insignificant number of females $8.33 \%$ give their opinion about both property and free movement. Buying and selling decision 50\% and food selection 33.33\% respondent, respectively (Fig 5).

The job environment is an important factor for the women workers of informal sector. In this study negligible percent $(5 \%)$ answered that they do not face any problem in their work-station, $1.67 \%$ of respondents have not answered and 93.3\% said that they have faced different forms of problems (Fig 6).

\section{These are as follows}

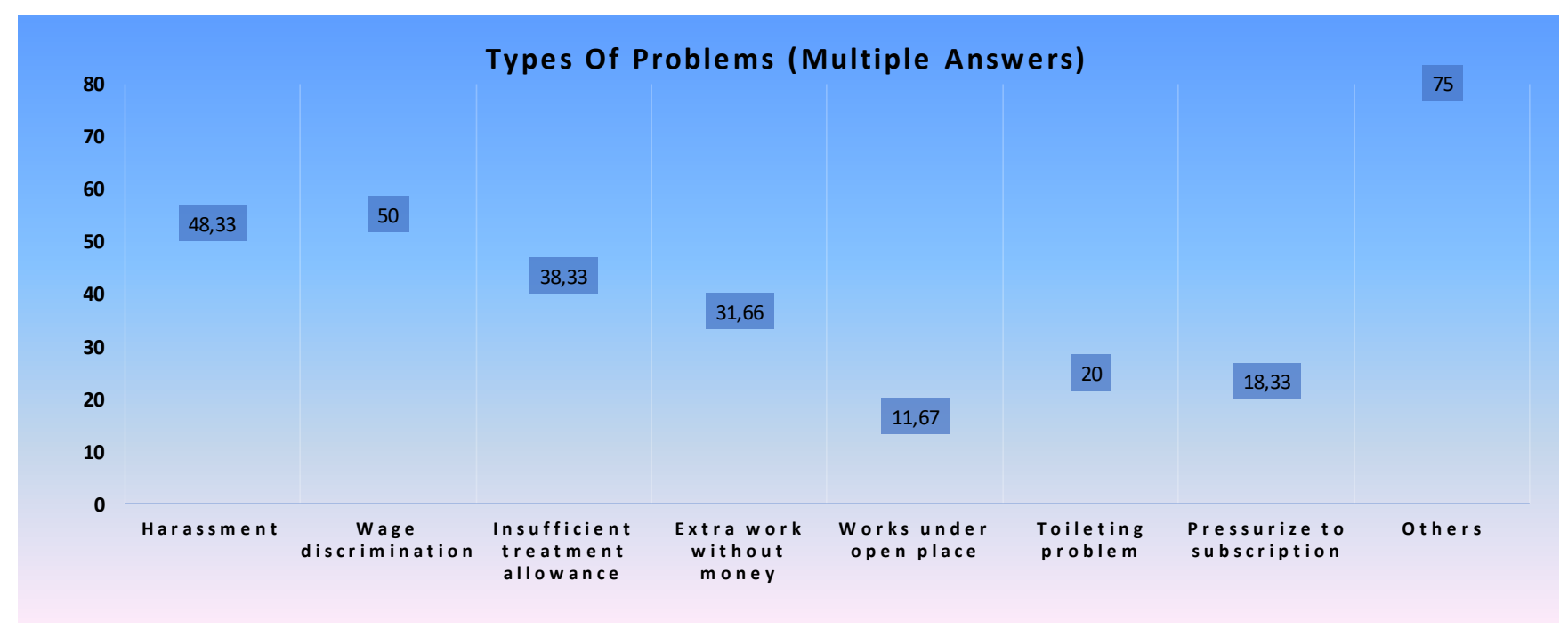

Fig 7: Types of problems (Multiple answers).

Opinion of informal women workers how they minimize their problems - Execute Policy as well as should be implemented, Trade union for women, \& Ensure Social Security. Factory Rules of 1979, Factory Act 1965, Bangladesh Labour Law (Amendment, 2013) allowed defense to labour potency. In this research, we found that most informal women worker is not aware of labour legislation. For that reason, they faced many kinds of problems in their working places. To reduce these conditions respondent or participant gave several opinions. $61.67 \%$ of respondent opined
In this study, we found that $48.33 \%$ of the percipients are harassed physically, mentally, sexually, or otherwise in their working places by their male colleagues, administration, or others. Lengthy working hours are the exhausting environment of the informal sector. $50 \%$ of women worker faced severe wage discrimination they said that where a male worker gets Tk.200.00 but a women worker gets Tk. 100.00 for the equivalent work and working hour. $38.33 \%$ of the respondent said when they are affected by illness or accident; they don't get sufficient medical/treatment allowances. $31.66 \%$ said that they never get any reward for extra work. $11.67 \%$ said they work under the open sky, 20\% said they do not get toilet facilities properly, $18.33 \%$ of the participant said that they faced pressure to subscription money police, political leader, local mastan, etc. $75 \%$ of the participant said they have no rest hour, they negligent by others and they have no maternity leave with pay (Fig 7). persecution free their work environment, $55 \%$ said equality opportunity for all. Providing toilet facilities $38.33 \%$, sufficient allowances (Medical, Transport, Festival, Incentives etc.) $71.67 \%$. Maternity leave is a humanitarian leave, but respondent said very few of them obtain it with salary and the majorities do not get it. $66.67 \%$ of respondent said to assure their maternity leave with pay. $20 \%$ wants to establish a daycare service and $63.33 \%$ wants a healthy workplace. 48.33\% opined formal training facilities should be introduced for them for their betterment. The highest 
number $83.33 \%$ of respondent think that their vulnerable situation will be modified if the government will be built policy for their working sector and affirm social security. These opinions are very significant for the informal female workers in Bangladesh (Fig 8).

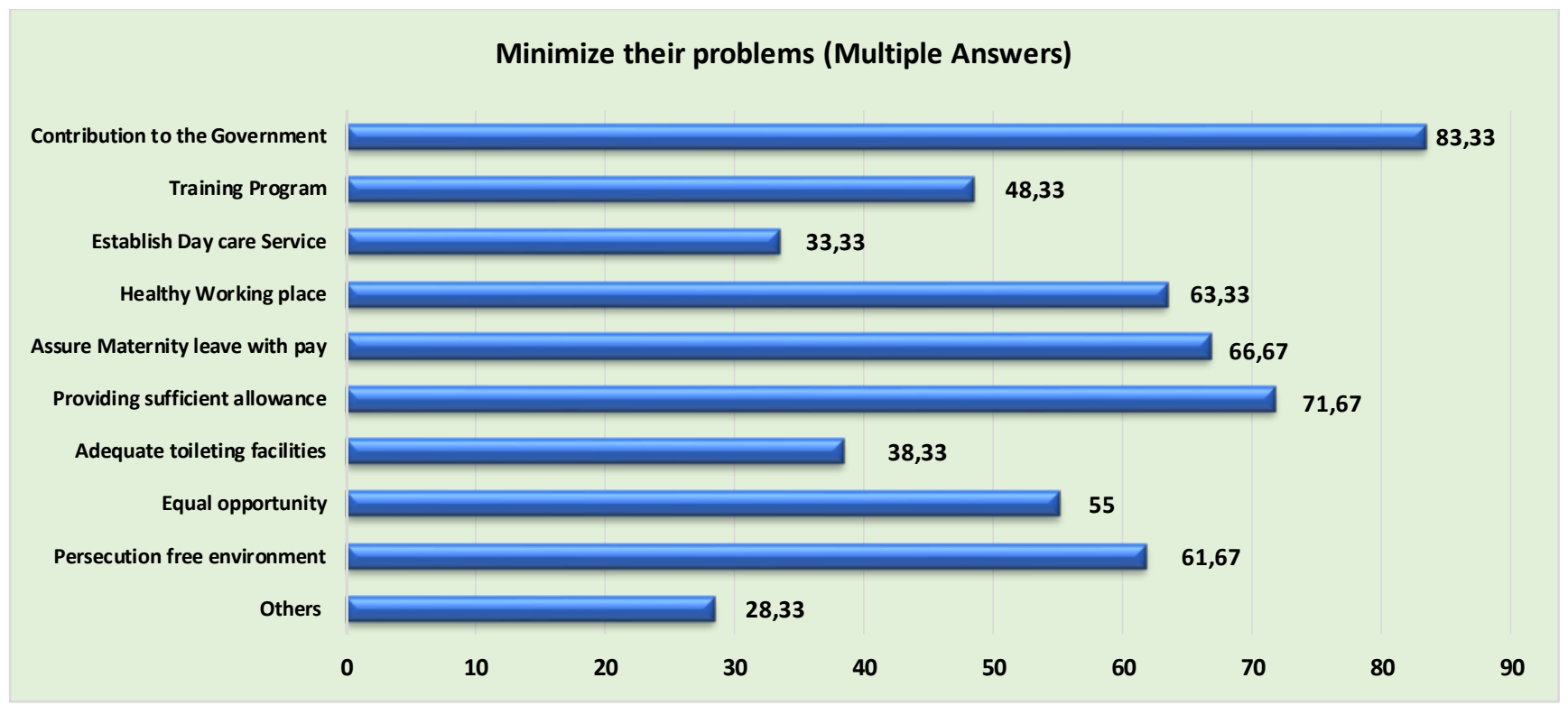

Fig 8: Minimize their problems (Multiple answers).

\section{CONCLUSION AND RECOMMENDATION:}

In this research, we found that most informal women workers are not aware of labour legislation. For that reason, they faced many kinds of problems in their working places. To reduce these conditions respondent or participant gave several opinions. $61.67 \%$ of respondent opined persecution free their work environment, 55\% said equality opportunity for all. Providing toilet facilities 38.33\%, sufficient allowances (Medical, Transport, Festival, Incentives etc.) $71.67 \%$. Maternity leave is a humanitarian leave, but respondent said very few of them obtain it with salary and the majority does not get it. $66.67 \%$ of respondent said to assure their maternity leave with pay. $20 \%$ wants to establish a daycare service and $63.33 \%$ wants a healthy workplace. $48.33 \%$ opined formal training facilities should be introduced for them for their betterment. The highest number $83.33 \%$ of respondent think that their vulnerable situation will be modified if the government will be built policy for their working sector and affirm social security. These opinions are very significant for the informal female workers in Bangladesh. At present times, the socio-economic condition of female workers in the informal sector has improved radically. On some social indicators like education, health and empowerment progress have been observed. But the women's contribution in the formal estimation of GDP is much lower than the men. The main causes of this are women's disproportionate engagement in the informal sector. A safe and secure working environment is the fundamental right of the laborers' (UDHR, 1948). But, in Bangladesh, these problems remain unsolved, because of the unwillingness of people and lack of enforcement mechanism. In this regards, (Nazmul Alam, 2012) mentioned that the female workers of informal sectors are felt unsafe and felt the hazardous atmosphere, but they similarly do not become medical treatment. Though as per the constitution of Bangladesh, there would not be any discrimination of wage and salary in the workplace based on gender. The main causes of it are the women workers in the informal sector are not highly educated. Only $37 \%$ of workers studied from class five to seven and $21 \%$ have passed school secondary (SSC). So, they are unaware of their rights. $40 \%$ women workers get only 4000-to-5000-taka salary monthly and their expenditure is almost same. So, they have no savings and no economic security. They are always afraid about losing their job and if they lose it, they will not be capable to survive even a month. So, they do whatever task they are given without any argument. This research finds that $70 \%$ of the female workers are 
transshipped to urban area. There are many causes for them to migrate. Like poverty, unemployment, natural disaster etc. That shows if the working opportunity could be created out of the urban area, these people would not come from rural areas. Even though the women workers overcome all these sufferings and join their work, they must face some new problems in the workplaces. $94 \%$ of women said they are facing several problems in their workplaces. Sometimes they face sexual harassment and some problems like discrimination against men on wages, no maternity leaves with pay, not enough toilet and wash-rooms, no daycare centre, lack of training, lack of transport etc. To speak frankly, the present condition of female in the informal sector of Bangladesh is like it's creating a great opportunity for our economy to enrich but the women workers of it are maintaining their life with great deprivation. We expect in future our country will take informal sector in topper position by maintaining proper management and policies. For this objective, the study suggests some recommendation to solve the difficulty and for the wellbeing of the women workers of the informal sector. The recommendations are:

- National policy should be updated, and the informal sector should get the priority.

- A common minimum wage range should be declared by the authority

- A large number of training opportunities should be created for workers to develop their skill.

- Saving them from physical, mental, and sexual harassments.

- Female workers should get respect in workplaces like men.

- Ensuring entertainment and accommodation facilities.

- Ensuring social security.

- Increasing women's role in household decision making.

Lack of research, the problems of women's dignity relate to women's work in informal sectors. In Dhaka women, workers do not feel hesitant about the prestige of informal works. But the local city outside of Dhaka feels hesitant to do informal works inlay of informal labour works. In that context, G. Rodgers mentioned that dignity or 'decent work' means the labour should gratify social norms in regards to income, conditions, security, rights of man, and dignity (Ademu, 2006). Therefore, since the researcher could not collect such information in the research, so it is one of the barriers to the research. The researcher believes that in future there will be a new study in this thought.

\section{ACKNOWLEDGEMENT:}

We are grateful to a lot of people for their support to conduct this study. First of all, we are thankful to the Gono Bishwabidyalay authority for giving us the opportunity for conducting this research. Some of our research students helped us to collect data and last but not the least some of our colleagues helped us highly to succeed this study. We are very much thankful to them for their support.

\section{CONFLICTS OF INTEREST:}

There are no potential conflicts of self-interest among the authors. Everyone has done his/her part and there is no argument with anybody.

\section{REFERENCES:}

1) Ademu, W.A. (2006). The informal sector and employment generation in Nigeria: The role of credit. Paper presented at the Annual Conference of the Nigerian Economic Society (NES). 22-24 August, Calabar, Nigeria

2) Alam, Md. Nazmul, (2012.). "A Socio-economic study of informal sector workers of Dhaka city in Bangladesh, e-J. of Sociology, 9(2); 101-108. https://www.researchgate.net/publication/230873894

3) Akhter Ms. Asma, (2018). "Women and Men in Bangladesh: Facts and Figures, BBS, Cooperation Bangladesh Bureau of Statistics (BBS), Swedish International Development Cooperation Agency (Sida) Statistics Sweden and UN Women. https://bbs.portal.gov.bd/sites/

4) Asian Development Bank (ADB), (2010). The Informal Sector and Informal Employment in Bangladesh, Country Report 2010- Asian Development Bank (ADB). Bangladesh Bureau of Statistics.

https://www.adb.org/sites/default/files/publication/ 30084/informal-sector-informal-employment-ban gladesh.pdf

5) Farrel, (2000). "Globalization and employment Generation" Evaluating the impact of trade on 
Aggregate employment in Nigeria's In Industrial Sector" NES 2000 Annual Conference, Nigeria.

6) Hossain Iqbal, (2018). Women labor force in Bangladesh: Key facts and trends, $26^{\text {th }}$ Anniversary Issue-III.

7) Hossain, Md. Kaium, Parag Jafar Siddique, (2015). Socio-Economic Analysis of Informal Business Activities: A Case Study on Central Business District Area of Dhaka City, Developing Country Studies, 5(7), pp. 1-11.

https://www.iiste.org/Journals/index.php/DCS/articl e/view/21310/21964

8) Islam Md. Nurul, (2014). Informal Sector of Bangladesh, Director, Bureau of Manpower Employment and Training Info Brief.

9) Islam Tahmidul, (2013). "Informal Sector in South Asia: A Case Study of Bangladesh". Global Journal of Human-Social Science: E Economics, 17(3); 2017.

https://globaljournals.org/GJHSS Volume17/1-In formal-Sector-In-South-Asia.pdf

10) Italo A. Gutierrez, Minhaj Mahmud, and Shanthi Nataraj, (2019). Transitions between informal and for-mal employment: results from a worker survey in Bangladesh, IZA Journal of Development and Migration, 9(1), pp. 1-27. https://izajodm.springeropen.com/articles/10.1186/ s40176-019-0141-2

11) Kapoor Aditi, (2007). The SEWA way: Shaping another future for informal labour, Elsevier, Futures 39, pp. 554-568.

12) Khatun Fahmida, Khan Towfiqul Islam, Shahida Pervin, Hosna Jahan, (2015). Estimating Women's Contribution to the Economy the Case of Bangladesh, CPD, MJF, pp. 1-122.

https://www.researchgate.net/publication/330703598

13) Mondal Md. Sanaul Haque, (2017). Urban Informal Economy in Bangladesh: A Case Study on Mobile Vegetable Vendor in Dhaka City. The Qualitative Report, 22(11), 2893-2903. https://doi.org/10.46743/2160-3715/2017.3106

14) Ojo, F. (1981). "Nigeria's Manpower Planning Experience", in F. Ojo, A. Aderinto and, Fasoyin (eds.), Manpower Development and Utilization in Nigeria: Problems and Policies, Lagos University Press, Lagos.

15) Rahman Mustafizur, Debapriya Bhattacharya, and Md. Al-Hasan, (2013). The role of the informal sector in inclusive growth a state of knowledge study from policy perspectives, Research Report 3. ODI, London-2013.

16) Raihan Selim et al. (2018). -“A research paper on Economic Dialogue on Inclusive Growth in Bangladesh" Female employment stagnation in Bangladesh, The Asia Foundation.

17) Rodgers, G. (2007). Labour Market Flexibility and Decent Work. DESA Working Paper 47, United Nations, New York, pp. 1-9. https://www.un.org/esa/desa/papers/2007/wp47 2 007.pdf

18) Sharma Khema, (2012). Role of Women in Informal Sector in India, IOSR Journal of Humanities and Social Science, 4(1), Pp. 29-36. http://iosrjournals.org/iosr-jhss/papers/Vol4-issue1/ D0412936.pdf

19) Ullah Md. Mamin, (2018). An Analysis of Division-wise Employment Patterns in Bangladesh: Decent Work Perspective, DUET Journal, 4(1); pp. 83-94.

20) Yasmin T., and Husna CA. (2020). Familial support as a determinant of women career development: a qualitative study, Asian J. Soc. Sci. Leg. Stud., 2(4), 76-87. https://doi.org/10.34104/ajssls.020.076087

Citation: Sultana MT, Ali MM, Parvin R, and Hasan M. (2021). The present scenario of women laborer in the informal sector: a study on Dhaka city, Asian J. Soc. Sci. Leg. Stud., 3(4), 128-138.

https://doi.org/10.34104/ajssls.021.01280138 C) () 